\title{
Iron oxide nanoparticles suppress the production of IL-1 beta via the secretory lysosomal pathway in murine microglial cells
}

Hsin-Ying Wu' ${ }^{1}$, Min-Chun Chung ${ }^{1}$, Chia-Chi Wang ${ }^{2}$, Chung-Hsiung Huang ${ }^{1}$, Hong-Jen Liang ${ }^{3 *}$ and Tong-Rong Jan ${ }^{1 *}$

\begin{abstract}
Background: Superparamagnetic iron oxide nanoparticles (IONPs) have been used as magnetic resonance imaging contrast agents for various research and diagnostic purposes, such as the detection of neuroinflammation and blood-brain-barrier integrity. As the central resident macrophage-like cells, microglia are responsible for managing foreign agents invading the CNS. The present study investigated the direct effect of IONPs on the production of pro-inflammatory cytokines by murine microglia stimulated with lipopolysaccharide (LPS).

Methods: Primary murine microglial cells were pretreated with IONPs (1-50 $\mu \mathrm{g} \mathrm{Fe} / \mathrm{mL})$ for $30 \mathrm{~min}$ and then stimulated with LPS $(100 \mathrm{ng} / \mathrm{mL})$ for $24 \mathrm{~h}$. Confocal microscopy is used to visualize the intracellular IONP distribution and secretory lysosomes after staining with LysoTracker and Rab27a, respectively. The production of interleukin (IL)-1 $\beta$ and tumor necrosis factor (TNF)- $a$ was quantified by ELISA. The activity of IL-1 $\beta$ converting enzyme (ICE) and TNF-a converting enzyme (TACE) was measured by fluorescent microplate assay using specific substrates. The lysosomal number, alkalinity, permeability and cathepsin B activity were determined by flow cytometry with ectodermal dysplasia-1, lysosensor and acridine orange staining, and using cathepsin B specific substrate, respectively.
\end{abstract}

Results: Confocal imaging revealed that IONPs were markedly engulfed by microglia. Exposure to IONPs attenuated the production of IL-1 $\beta$, but not TNF-a. Concordantly, the activity of ICE, but not the TACE, was suppressed in IONPtreated cells. Mechanistic studies showed that IONPs accumulated in lysosomes and the number of lysosomes was increased in IONP-treated cells. In addition, exposure to IONPs increased lysosomal permeability and alkalinity, but decreased the activity of cathepsin B, a secretory lysosomal enzyme involved in the activation of ICE.

Conclusions: Our results demonstrated a contrasting effect of IONPS on the production of IL-1 $\beta$ and TNF-a by LPS-stimulated microglia, in which the attenuation of IL-1 $\beta$ by IONPs was mediated by inhibiting the secretory lysosomal pathway of cytokine processing.

Keywords: Cathepsin B, Interleukin-1 $\beta$, Iron oxide nanoparticle, Lipopolysaccharide, Microglia, Secretory lysosome

\footnotetext{
* Correspondence: jenliang@mail.ypu.edu.tw; tonyjan@ntu.edu.tw

${ }^{3}$ Department of Food Science, Yuanpei University, No.306, Yuanpei Street, Hsinchu 30015, Taiwan

${ }^{1}$ Department and Graduate Institute of Veterinary Medicine, School of Veterinary Medicine, National Taiwan University, No.1, Sec. 4, Roosevelt Road, Taipei 10617, Taiwan

Full list of author information is available at the end of the article
} 


\section{Background}

Iron oxide nanoparticles (IONPs) have been employed for a variety of biomedical research and diagnostic purposes, including cancer treatment, cell labeling, drug delivery and magnetic resonance imaging (MRI) [1-4]. Previous studies reported that IONPs affected the viability and functionality of macrophages, including the induction of oxidative stress and apoptosis, and the suppression of phagocytic activity and cytokine production [5-9]. In addition, IONPs have been shown capable of crossing the blood-brain-barrier, rendering IONPs a promising imaging agent for the diagnosis of neuroinflammation and brain injury [10-12]. In light of the increasingly applications of IONPs for the diagnostic imaging of the central nervous system (CNS), the interaction between brain cells and IONPs is a relevant issue to be addressed. To date, it remains mostly elusive if IONPs influence the functionality of central immune cells, such as microglia.

Microglia are the brain-resident macrophage-like immunocompetent cells responsible for the surveillance of homeostasis in the CNS. In response to pathogen infection, foreign agent invasion and injury, microglia are rapidly activated, and undergo morphologic and functional alterations, including proliferation, migration to the site of inflammation, and phagocytosis of foreign agents and cell debris. In addition, activated microglia produce pro-inflammatory cytokines and cytotoxic factors, including interleukin (IL)-1 $\beta$, nitric oxide (NO), tumor necrosis factor (TNF)- $\alpha$ and reactive oxygen species (ROS) [13,14]. These mediators play a key role in the prevention of brain cells from further damage and to promote the repair of the damaged tissue. For example, IL-1 $\beta$ produced by activated microglia enhances the proliferation of astrocytes, stimulates neovascularization and promotes the repair of nervous tissues [15-18]. Microglial TNF- $\alpha$ can promote neural cell survival and proliferation, and enhance the release of glutamate from astrocytes $[19,20]$. Previous studies reported that intranasal administration of gold nanoparticles to mice induced microglial activation and internalization of gold nanoparticles, and a transient up-regulation of Toll-like receptor-2 in the olfactory bulb [21]. In addition, intranasal exposure of mice to IONPs resulted in the transportation of the nanoparticles into the brain via the olfactory route, and induced the recruitment, activation and proliferation of microglia cells in the brain. Exposure of BV2 microglial cells to IONPs elicited a marked production of ROS and NO. IONPs were also found to be engulfed by BV2 cells, which induced a large number of cellular vesicles, swelling of endoplasmic reticulum and morphological alterations of mitochondrial cristae [22]. Collectively, these results indicate that the functionality and morphology of resting microglia are altered in response to nanoparticle exposure. Microglia play a pivotal role in neuroinflammation, in which they can be activated by various stimuli, such as lipopolysaccharides (LPS) derived from Gram-negative bacteria. To date, evidence pertaining to the potential impact of IONPs on the functionality of activated microglia is scarce. The objective of the present study was to investigate the effect of IONPs on the expression of pro-inflammatory cytokines by LPS-activated microglia. Here, we reported that IONPs suppressed the production of IL- $1 \beta$ by activated microglia via the secretory lysosomal pathway of cytokine processing.

\section{Results and discussion Characterization of IONPs and uptake of IONPs by primary microglia}

The present study employed the commercial preparation of carboxydextran-coated IONPs Resovist ${ }^{\circledR}$ that has been used in clinical as an imaging contrasting agent. The crystalline core of Resovist ${ }^{\circledR}$ is composed of magnetite $\left(\mathrm{Fe}_{3} \mathrm{O}_{4}\right)$ and maghemite $\left(\mathrm{Fe}_{2} \mathrm{O}_{3}\right)$. According to the package insert of Resovist ${ }^{\circledR}$, the hydrodynamic diameters of the nanoparticles range between 45-60 nm. Our confirmatory experiments revealed that Resovist ${ }^{\circledR}$ exhibited a monodisperse population of particles with an average diameter of $58.7 \mathrm{~nm}$ in saline [23]. The zeta potentials of the particles in saline and in the culture medium were $-13.9 \mathrm{mV}$ and $-9.01 \mathrm{mV}$, respectively. IONPs in culture medium remained a similar net negative-charge as in the serum-free saline. Primary microglial cells were pretreated with IONPs $(1-50 \mu \mathrm{g}$ $\mathrm{Fe} / \mathrm{mL})$, and then stimulated with LPS $(100 \mathrm{ng} / \mathrm{mL})$ for $24 \mathrm{~h}$. Confocal microscopy was used to monitor the uptake of IONPs, and the images showed the accumulation of dark brown dots in the cytoplasm of cells exposed to IONPs (Figure 1A). These results confirmed the uptake of IONPs by phagocytic cells [9,24-26].

\section{IONPs did not affect the viability of primary microglia}

Although IONPs are generally considered biocompatible, high concentrations of IONPs have been reported to cause cytotoxicity in several glial lines [27]. Moreover, IONPs induced the disappearance of mitochondrial cristae and swelling of endoplasmic reticulum (ER) in BV2 microglial cells [22]. Five-day exposure to IONPs elicited ROS-mediated apoptosis in human macrophages [6]. Other metal nanoparticles such as titanium dioxide also induced apoptosis in murine N9 microglial cells [28]. It is currently unclear whether IONPs affect the viability of primary microglia. Hence, the cell viability was measured using the 3-(4,5-dimethylthiazol-2-yl)-2,5-diphenyl-tetrazolium bromide (MTT) assay. Exposure to IONPs (1-50 $\mu \mathrm{g} \mathrm{Fe} / \mathrm{mL})$ for $24 \mathrm{~h}$ did not affect cell viability compared to the LPSstimulated control group (Figure 1B), and the morphology of cells appeared unchanged (Figure 1A). These 
A

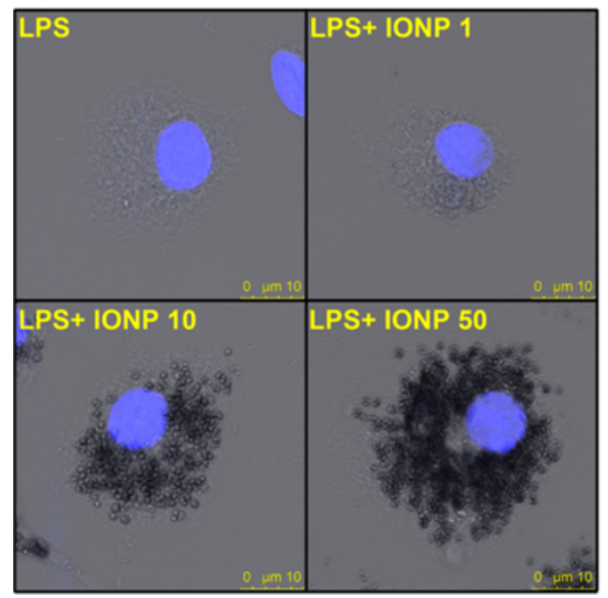

B

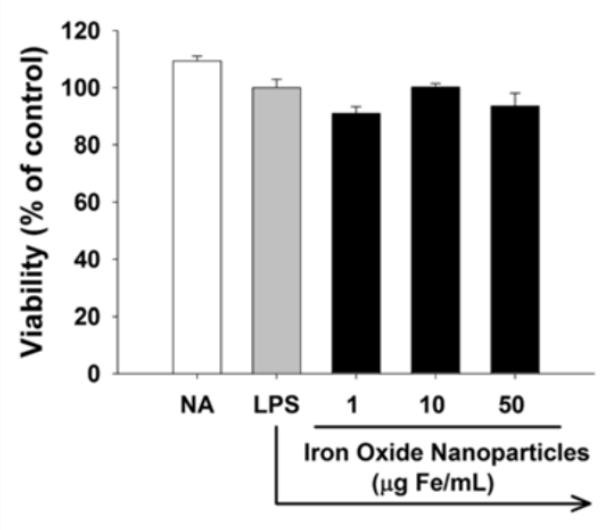

Figure 1 Exposure to iron oxide nanoparticles (IONPs) did not cause cytotoxicity to primary microglial cells. Primary microglial cells $\left(4 \times 10^{5}\right.$ cells $/ \mathrm{mL}$ ) were either left untreated (naïve; NA), or pretreated with IONPs (1-50 $\left.\mathrm{mg} \mathrm{Fe} / \mathrm{mL}\right)$ for 30 min followed by stimulation with LPS $(100 \mathrm{ng} / \mathrm{mL})$ for $24 \mathrm{~h}$. (A) The nuclei of cells pretreated with IONPs and stimulated with LPS were visualized by confocal microscopy with Hoechst (blue) staining. In the bright field, cells treated with IONPs show numerous dark brown dots accumulated intracellularly. (B) The cell viability was determined by the MTT assay. Data are expressed as the mean \pm SE of triplicate cultures. Results are a representative of three

independent experiments.

results are in line with previous results showing that a 24-h exposure of macrophages to carboxydextran-coated IONPs induced no cytotoxicity $[6,9,29]$.

\section{IONPs differentially modulated the production of} proinflammatory cytokines by LPS-stimulated microglia

To address the potential impact of IONPs on the functionality of activated microglia, we examined the production of IL- $1 \beta$ and TNF- $\alpha$ by LPS-stimulated microglia. Exposure to IONPs significantly attenuated the production of IL-1 $\beta$, but not TNF- $\alpha$ (Figure $2 \mathrm{~A}$ and $2 \mathrm{~B}$ ). The maturation of IL- $1 \beta$ and TNF- $\alpha$ requires the proteolytic cleavage of pro-IL-1 $\beta$ and pro-TNF- $\alpha$ by IL- $1 \beta$ converting enzyme (ICE; caspase- 1 ) and TNF- $\alpha$ converting enzyme (TACE), respectively $[30,31]$. Hence, the activity of these two enzymes was measured using specific fluorescent substrates. Consistent with the differential effect on cytokine production, exposure to IONPs $(50 \mu \mathrm{g} / \mathrm{mL})$ significantly attenuated the activity of ICE, but not TACE (Figure 2C and 2D). These results provide the first evidence to show that direct exposure to IONPs differentially modulated the production of IL- $1 \beta$ and TNF- $\alpha$ by LPSstimulated microglia.

Cytokines can be processed via the classical or nonclassical secretory pathway. In particular, TNF- $\alpha$ is released through the classical pathway, in which newly synthesized pro-TNF- $\alpha$ was trafficked from the ER through the Golgi to recycling endosomes, which fused with cell membrane for the cleavage of pro-TNF- $\alpha$ by TACE and then exocytotic release of mature TNF- $\alpha$ $[32,33]$. In contrast to the processing of TNF- $\alpha$, IL- $1 \beta$ lacks the $N$-terminal signal sequence required for ER entry and thus is released through the non-classical pathway independent of ER/Golgi trafficking [34]. Several mechanisms associated with the release of IL-1 $\beta$ have been proposed, including the exocytosis of IL-1 $\beta$ containing secretory lysosomes, shedding of plasma membrane microvesicles, release of IL- $1 \beta$ exosomes from multivesicular bodies and export of IL- $1 \beta$ through ATP-binding cassette transporters [35,36]. Previous studies showed that silica-based nanoparticles inhibited the mRNA expression of TNF- $\alpha$ by microglia [37]. Interestingly, our data revealed that exposure of LPSstimulated microglia to IONPs inhibited ICE activity and IL-1 $\beta$ secretion, whereas TACE and TNF- $\alpha$ were unaltered (Figure 2), indicating that the non-classical secretory pathway, rather than the ER/Golgi classical secretory pathway, was affected by IONPs.

\section{IONPs located in lysosomes and increased the number of}

\section{lysosomes}

Previous studies reported the accumulation of IONPs in lysosomes of macrophages [38]. Gold nanoparticles also accumulated in lysosomes of N9 microglial cells [21], implicating that lysosomes may be a critical intracellular target for nanoparticles in phagocytic cells. In addition, it has been shown that the lysosomal enzyme cathepsin $B$ plays a key role in the processing and maturation of IL-1 $\beta$ in activated microglia [39]. To elucidate the underlying mechanisms for IONP-mediated differential effects on the production of IL- $1 \beta$ and TNF- $\alpha$, the functionality of lysosomes was studied. The intracellular 

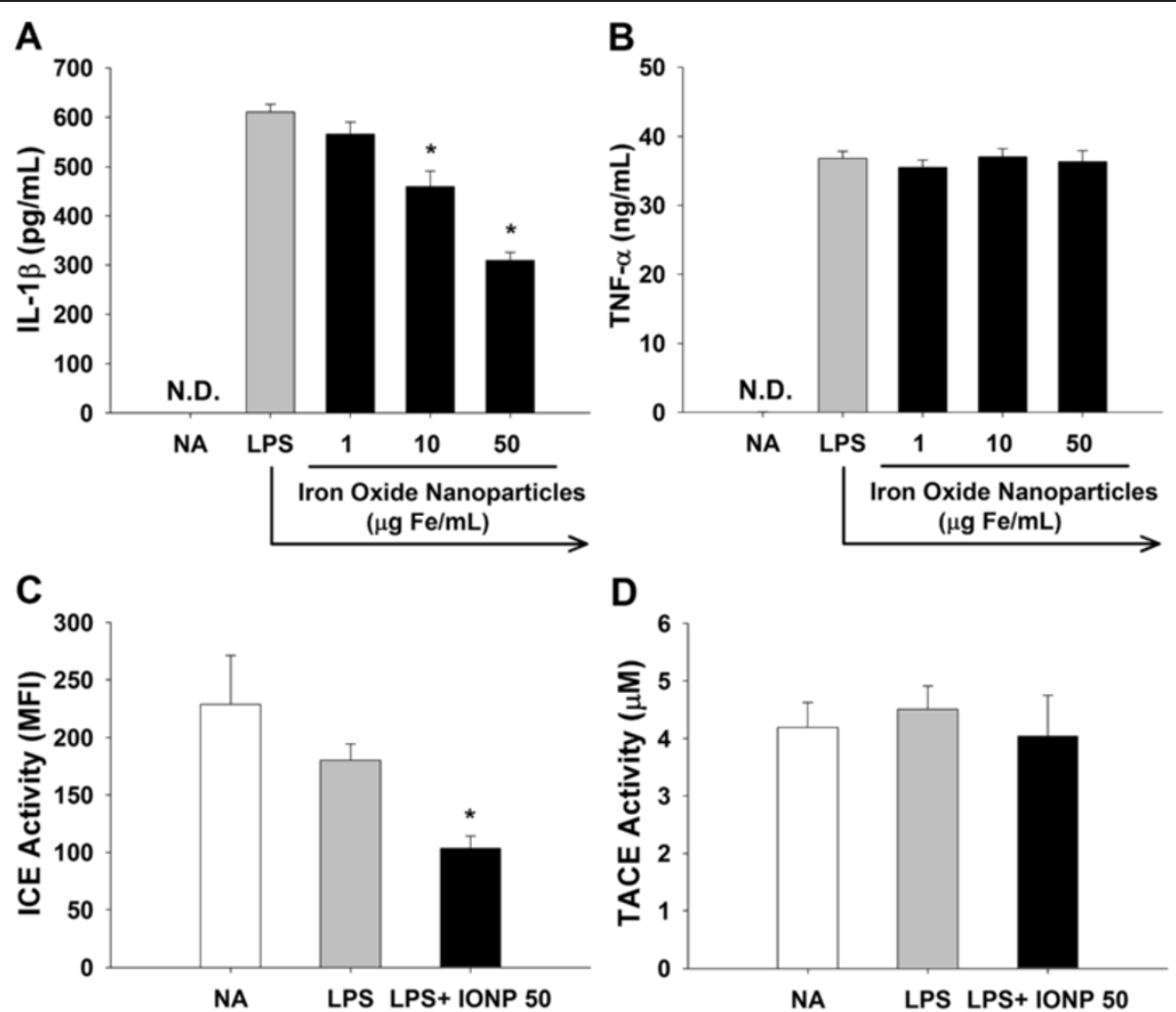

Figure 2 IONPs differentially affected the production of IL-1 $\beta$ and TNF- $\alpha$, and the activity of ICE and TACE in LPS-stimulated microglia. Primary microglial cells $\left(4 \times 10^{5}\right.$ cells $\left./ \mathrm{mL}\right)$ were either left untreated (naïve; NA), or pretreated with IONPs (1-50 $\mu \mathrm{g}$ Fe/mL) for $30 \mathrm{~min}$ followed by stimulation with LPS $(100 \mathrm{ng} / \mathrm{mL})$ for $24 \mathrm{~h}$. (A and B) The level of IL-1 $\beta$ and TNF-a in the supernatants was measured by ELISA. (C and D) The cell lysates were incubated with fluorogenic ICE or TACE substrates for $1 \mathrm{~h}$ at $37^{\circ} \mathrm{C}$. The fluorescence of cleaved substrates was detected using a fluorescent microplate reader. Data are expressed as the mean \pm SE of triplicate cultures. N.D., the level of IL-1 $\beta$ and TNF-a was below the limit of detection. ${ }^{*} p<0.05$ compared to the LPS group. Results are a representative of three independent experiments. MFI, mean fluorescence intensity.

distribution of IONPs was examined by confocal microscopy using the lysosomal marker LysoTracker ${ }^{\text {rix }}$ Red DND99. We revealed that many of dark brown dots in the cytoplasm were colocalized with the red fluorescence of LysoTracker ${ }^{\mathrm{rm}}$, demonstrating the distribution of IONPs in lysosomes (Figure 3A). We also observed that some lysosomes did not contain nanoparticle dots, and that some internalized IONPs did not colocalize with lysosomes (Figure 3A). Hence, not all IONPs were located in lysosomes. Previous results showed that IONPs could be endocytosed by macrophages and microglia $[22,38,40,41]$. We therefore speculate that IONPs may distribute in cytoplasmic compartments other than lysosomes, such as endosomes, which may account for the observed nonlysosomal distribution of IONPs. Next, we investigated the effect of IONPs on the number of lysosomes by measuring the expression of the macrophage/microglia specific lysosomal membrane protein ectodermal dysplasia (ED)-1. Exposure to IONPs markedly increased the expression of ED-1 (Figure 3B), indicating that the number of lysosomes was increased. Our results are in agreement with previous results showing that intranasal exposure of mice to IONPs resulted in an increased number of lysosomes in microglia [22].

\section{IONPs attenuated the activity of cathepsin B}

Secretory lysosomes serve both as a degradative and as a secretory compartment. To date, most cell types containing secretory lysosomes are hematopoietic lineagederived immunocytes, including dendritic cells, lymphocytes, macrophages, etc. [42,43]. It remains unclear if microglia possess secretory lysosomes. The secretory lysosomes were examined by determining the expression of Rab27a, a small GTPase involved in the fusion of secretory lysosomes with plasma membrane during the final stage of cytokine exocytosis [43,44]. In addition to lysosomal exocytosis, Rab27a has been associated with exosome secretion [45]. As shown in Figure 4A, the merge image of LPS-stimulated microglia showed a diffuse distribution of orange signals, demonstrating the colocalization of cathepsin B and Rab27a. Notably, very few red (cathepsin B-single positive) signals were observed in the merged 


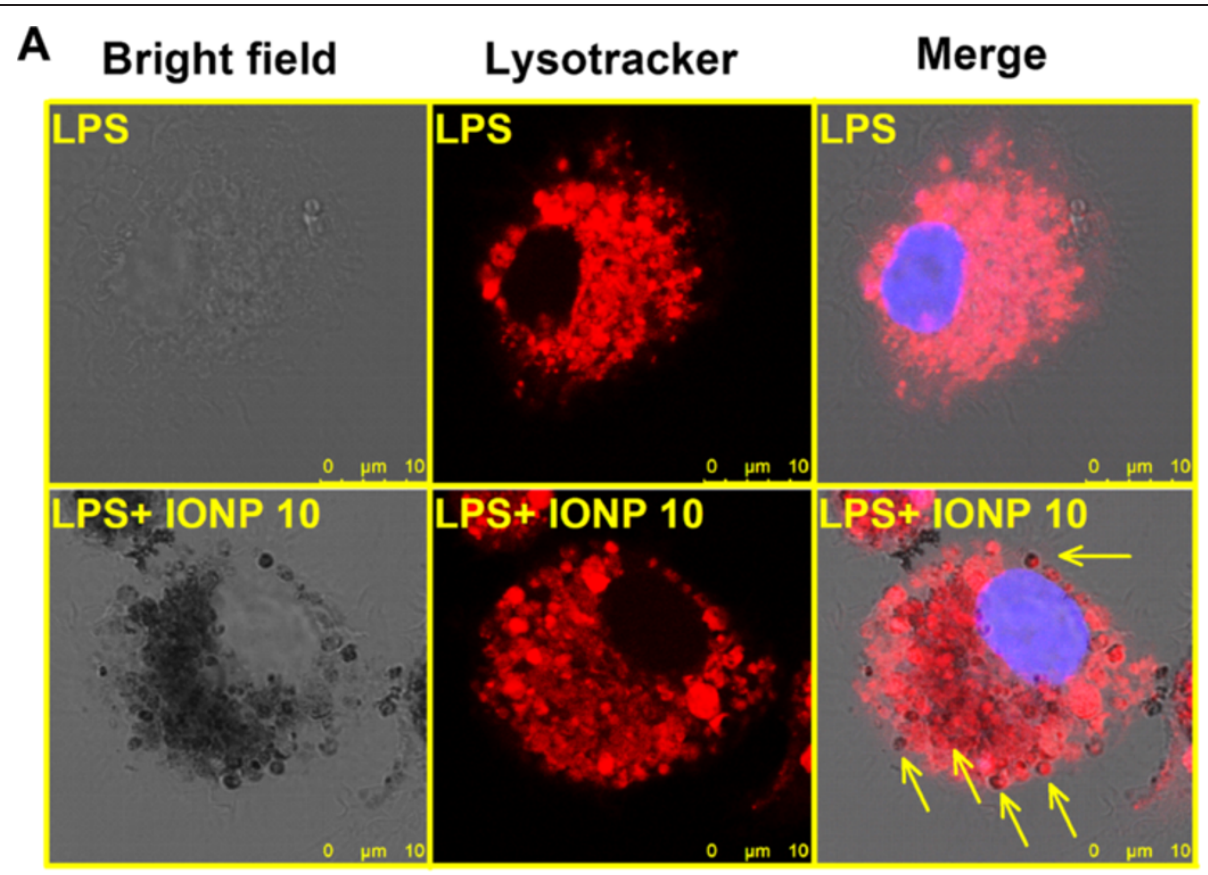

B

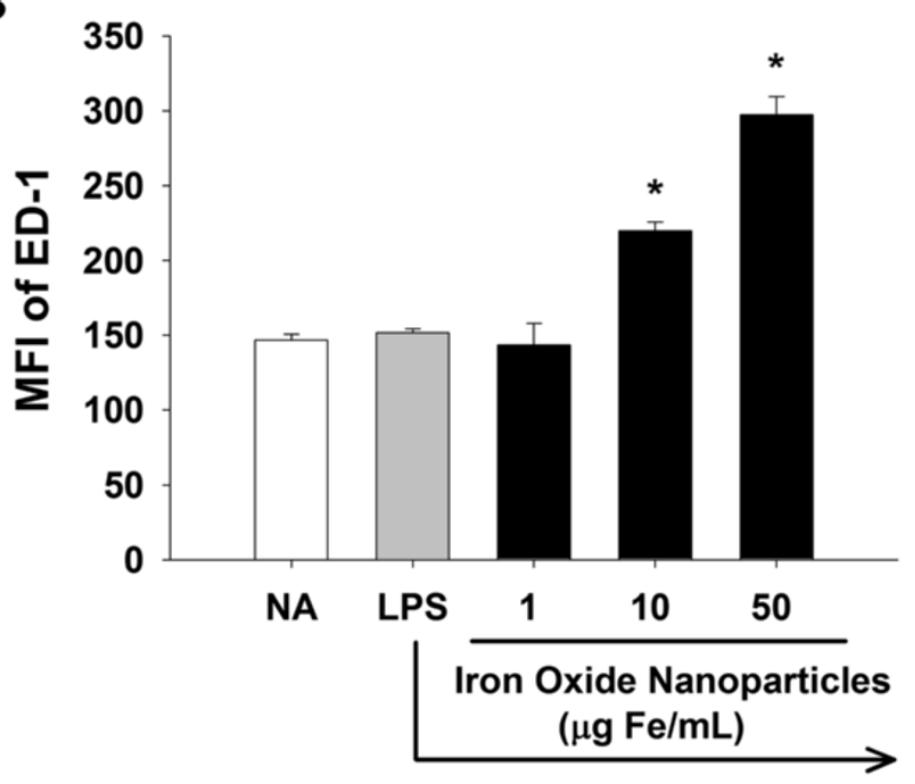

Figure 3 IONPs located in lysosomes and increased the number of lysosomes in LPS-stimulated microglia. Primary microglial cells $\left(4 \times 10^{5}\right.$ cells $/ \mathrm{mL}$ ) were either left untreated (naïve; NA), or pretreated with IONPs $(1-50 \mu \mathrm{g} \mathrm{Fe} / \mathrm{mL})$ for 30 min followed by stimulation with LPS $(100 \mathrm{ng} / \mathrm{mL}$ ) for 24 h. (A) The lysosomes of cells were visualized by confocal microscopy with LysoTracker (red) staining. Cells treated with IONPs show an extensive distribution of the internalized dark brown dots of IONPs. Arrows indicate the colocalization of some dark brown spots and lysosomes. (B) The expression of ED-1 was measured by flow cytometry. Data are expressed as the mean \pm SE of triplicate cultures. Results are a representative of three independent experiments. ${ }^{*} p<0.05$ compared to the LPS group. MFI, mean fluorescence intensity.

image, suggesting that cathepsin B was primarily located in Rab27a-positive sites. As cathepsin B is a critical lysosomal protease [46,47], these results suggest that the colocalization signals primarily represent secretory lysosomes, rather than exosomes. We also observed some green (Rab27a-single positive) signals in the merged image, demonstrating that some of Rab27a-positive sites were not lysosomes, which might be exosomes. Further studies are required to address this notion. We further observed that exposure to IONPs markedly attenuated red (cathepsin $\mathrm{B}$-single positive) and the merged orange signals (Figure 4A). Quantitative data from flow cytometry confirmed that exposure to IONPs (10-50 $\mu \mathrm{g} \mathrm{Fe/}$ $\mathrm{mL}$ ) significantly attenuated the cathepsin B activity 


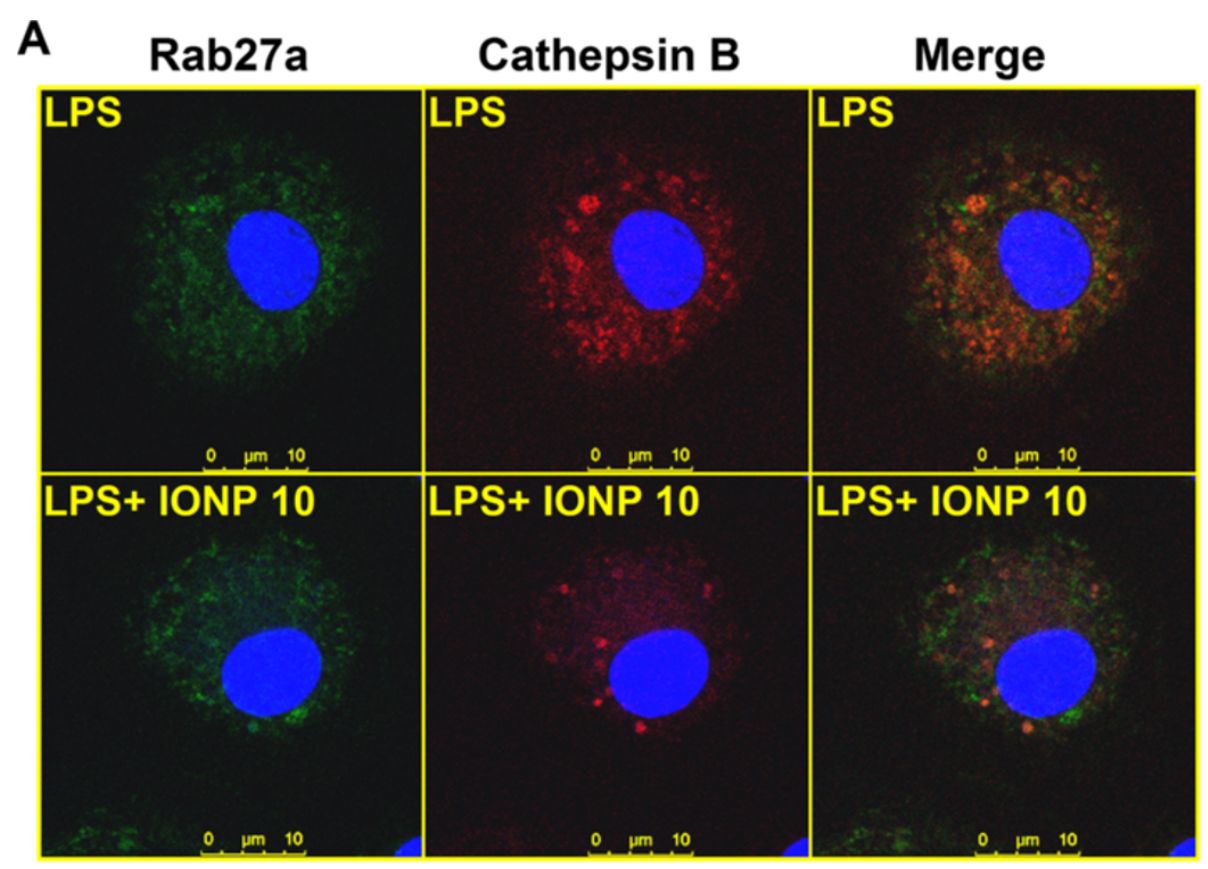

B

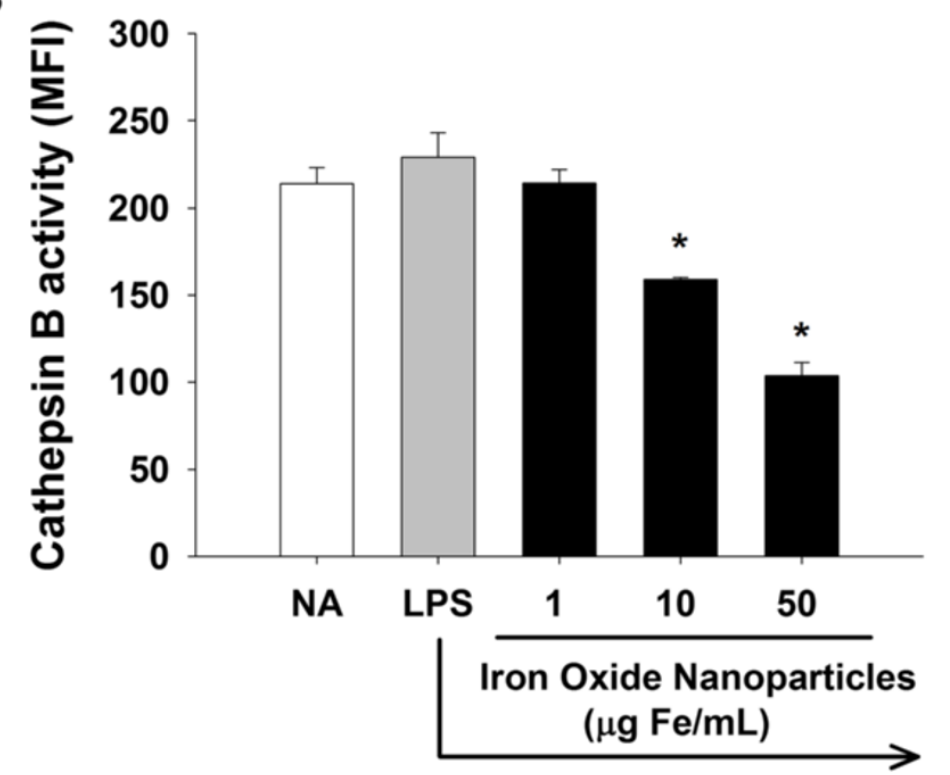

Figure 4 IONPs attenuated the cathepsin B enzyme activity of secretory lysosomes in LPS-stimulated microglia. Primary microglial cells $\left(4 \times 10^{5}\right.$ cells $/ \mathrm{mL}$ ) were either left untreated (naïve; NA), or pretreated with IONPs (1-50 $\mu \mathrm{g} \mathrm{Fe} / \mathrm{mL}$ ) for 30 min followed by stimulation with LPS $(100 \mathrm{ng} / \mathrm{mL})$ for $24 \mathrm{~h}$. (A) The cells pretreated with IONPs and stimulated with LPS were incubated with the cathepsin B substrate (red) for $1 \mathrm{~h}$ at $37^{\circ} \mathrm{C}$ and then stained for the secretory lysosome marker Rab27a (green). The fluorescence was visualized by confocal microscopy. Note the presence of orange signals in the merged images indicating the colocalization of cathepsin B and Rab27a. (B) The red fluorescence of 5000 single cells was measured by flow cytometry. Data are expressed as the mean \pm SE of triplicate cultures. Results are a representative of three independent experiments. ${ }^{*} p<0.05$ compared to the control group. MFI, mean fluorescence intensity.

(Figure 4B). These results showed for the first time that IONPs attenuated the cathepsin B activity in the secretory lysosomes of microglia. As cathepsin B is involved in the processing of IL- $1 \beta$ in activated microglia [39], we speculate that IONPs may affect the secretory lysosomal pathway of IL-1 $\beta$ processing.
IONPs elevated lysosomal alkalinity and permeability

The acid environment in lysosomes is crucial for the optimal function of lysosomal enzymes [48]. The acidity of lysosomes was measured by flow cytometry using LysoSensor Green DND-189, which emits fluorescence in acidic organelles, such as lysosomes [49]. The fluorescent 
intensity of LysoSensor was markedly attenuated in IONP-treated cells (Figure 5A and 5B), indicating an increased $\mathrm{pH}$ in lysosomes. We next examined whether IONPs affected the permeability of lysosomes using acridine orange that can be trapped in lysosomes and emits red fluorescence. Exposure of microglia to IONPs attenuated acridine orange fluorescence (Figure 5C and 5D), indicating an increased lysosomal permeability. Collectively, these results suggest that exposure to IONPs might impair lysosomal functions by increasing the lysosomal permeability and alkalinity in LPS-stimulated microglia. Our findings are in line with previous results showing that gold nanoparticles impair lysosomal degradation by elevating the lysosomal alkalinity in rat normal kidney cells [49]. Moreover, the disruption of lysosomal integrity could be a critical mechanism contributing to IONP-mediated suppression of the secretory lysosomal processing of IL-1 $\beta$ production in LPS-stimulated microglia.
IL- $1 \beta$ is one of the major pro-inflammatory cytokine produced by activated microglia, which induces the production of IL-6 and NO in astrocytes [16,17], and increase oxidative activity in microglia [50]. In addition, IL-1 $\beta$ released by microglia induces the proliferation of astrocytes, stimulates neovascularization and promotes repair of the CNS in brain injury $[15,18]$. In the present study, we showed that IONPs attenuated IL-1 $\beta$ production by suppressing the secretory lysosomal functionality in LPS-stimulated microglia. These results suggest that IONPs might impair the host defense against pathogens and the repairing capacity in the CNS. In addition, microglia are the major immunocompetent cells possessing antigen-presenting functions in the CNS [16]. It has been shown that lysosomal cysteine proteases, including cathepsin $\mathrm{B}$, are involved in the regulation of antigen processing in APC [51]. Our data showing the suppression of cathepsin B activity by IONPs suggest that the microglial

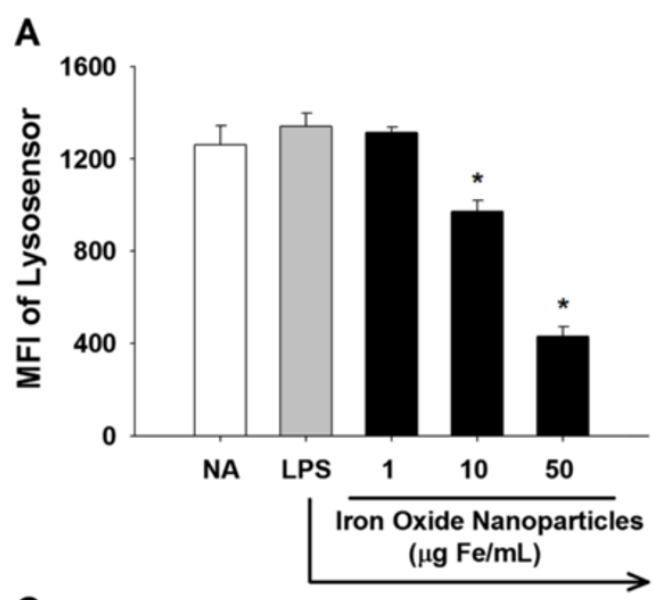

B
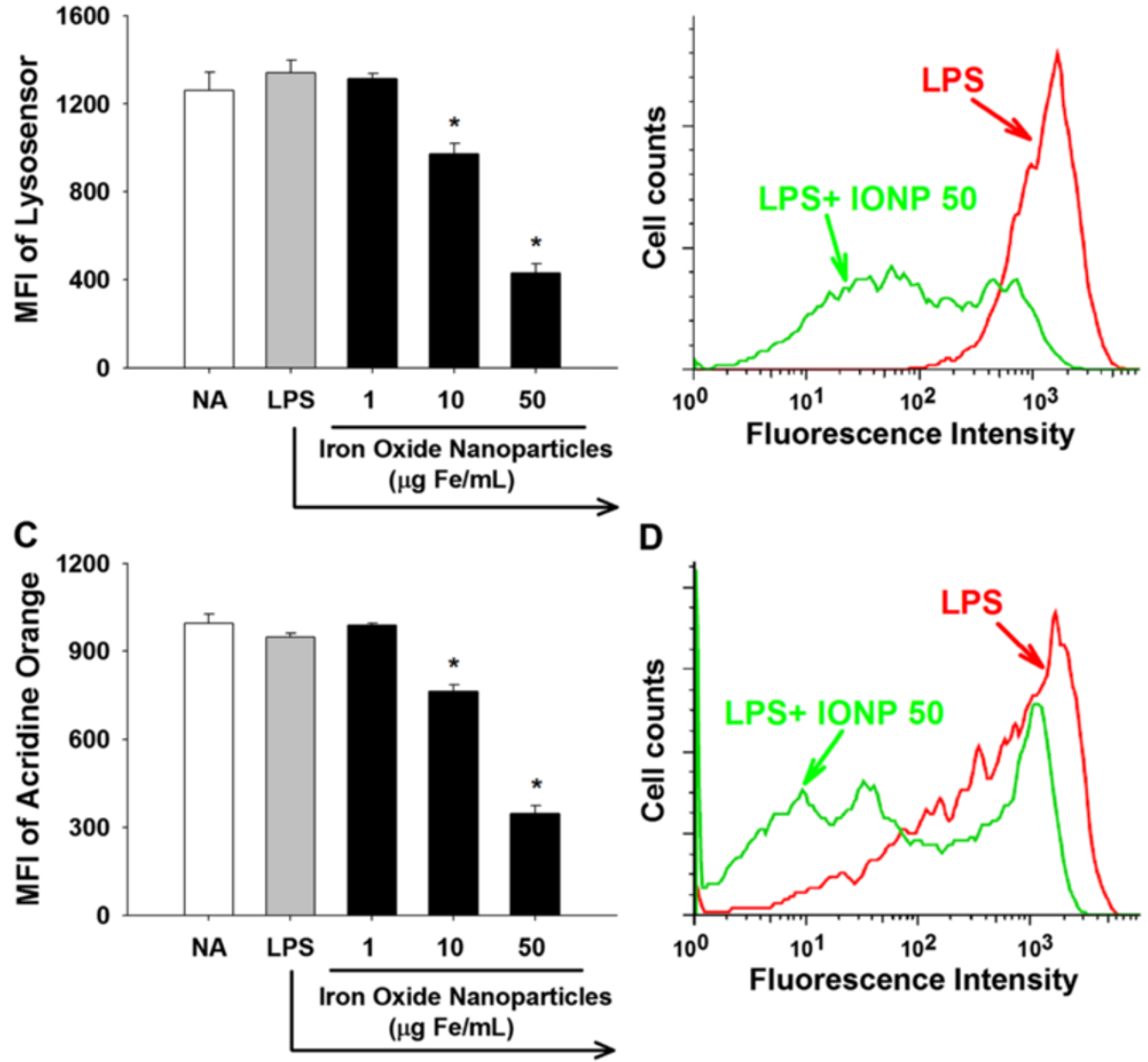

D

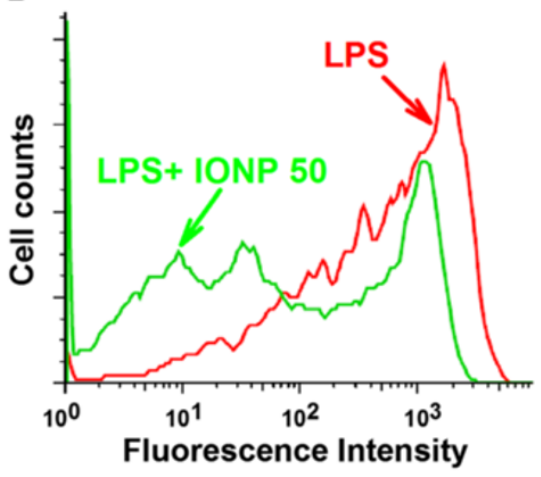

Figure 5 IONPs increased the alkalinity and permeability of lysosomes in LPS-stimulated microglia. Primary microglial cells $\left(4 \times 10^{5}\right.$ cells/ $\mathrm{mL}$ ) were either left untreated (naïve; NA), or pretreated with IONPs (1-50 $\mu \mathrm{g} \mathrm{Fe} / \mathrm{mL}$ ) for $30 \mathrm{~min}$ followed by stimulation with LPS (100 $\mathrm{ng} / \mathrm{mL})$ for 24 h. (A and $\mathbf{B}$ ) The acidity of lysosomes was evaluated by flow cytometry with lysosensor Green DND-189 staining. (C and D) The permeability of microglial cells were measured by flow cytometry with acridine orange staining. (B and D) Representative histograms of lysosensor and acridine orange in cells pretreated with IONPS $(50 \mu \mathrm{g} \mathrm{Fe} / \mathrm{mL})$ and stimulated with LPS were shown. Data are expressed as the mean \pm SE of triplicate cultures. Results are a representative of three independent experiments. ${ }^{*} p<0.05$ compared to the LPS group. MFI, mean fluorescence intensity. 
capability of antigen processing may also be affected. Further studies are warranted to address this issue.

\section{Conclusions}

The present study showed that IONPs accumulated in lysosomes and suppressed the production of IL-1 $\beta$ by affecting the secretory lysosomal pathway of cytokine processing in LPS-stimulated microglia. These findings provide new insights to the potential impact of IONP exposure on the functionality of activated microglia and indicate lysosomes as a crucial intracellular target for IONPs. Together with previous reports showing various effects on microglial functionality by other nanoparticles, including gold, silica, and titanium oxide $[21,37,49,52]$, exposure to nanoparticles may cause microglial dysfunction leading to deleterious influence on the central immune homeostasis.

\section{Methods}

\section{Materials}

All reagents were purchased from Sigma Chemical (St Louis, MO) unless otherwise stated. Resovist ${ }^{\circledR}$, a commercial preparation of carboxydextran-coated iron oxide nanoparticles (IONPs) containing $28 \mathrm{mg} \mathrm{Fe} / \mathrm{mL}$, was obtained from Schering AG (Berlin, Germany). Dulbecco's Modified Eagle Medium (DMEM) was obtained from Caisson Laboratories (Rexburg, ID). Fetal bovine serum (FBS), horse serum (HS) and cell culture reagents were purchased from GIBCO BRL (Gaithersburg, $\mathrm{MD})$. Enzyme-linked immunosorbent assay (ELISA) sets for cytokine measurement were purchased from BD Biosciences (San Diego, CA). ICE/Caspase 1 protease assay kit and fluorogenic substrates Ac-YVAD-AFC (7-amino-4-methylcoumarin) were obtained from Chemicon (Temecula, CA) and Tocris (Bristol, UK), respectively. TACE fluorogenic activity assay kit was purchased from AnaSpec (San Jose, CA). Magic Red ${ }^{\mathrm{Tm}}$ cathepsin B detection kit was purchased from Immunochemistry Technologies (Bloomington, $\mathrm{MN}$ ).

\section{Culture of primary murine microglial cells}

Primary mix glial cultures were prepared as previously described with minor modifications [53]. Briefly, after decapitation, forebrains of new-born BALB/c mice were dissociated mechanically. Their meninges were removed aseptically and the brain cells were resuspended in DMEM containing 10\% FBS, $10 \% \mathrm{HS}, 4 \mathrm{mM}_{\mathrm{L}}$-glutamine, $100 \mathrm{U} / \mathrm{mL}$ penicillin and $100 \mu \mathrm{g} / \mathrm{mL}$ streptomycin. The cells were cultured on poly-D-lysine $(25 \mu \mathrm{g} / \mathrm{mL})$ coated flasks, and medium was replenished 6-8 days after initial seeding. Upon reaching confluence (12-16 days), loosely adherent microglial cells were collected by shaking at $165 \mathrm{rpm}$ at $37^{\circ} \mathrm{C}$ for $3 \mathrm{~h}$. The enriched microglial cells were cultured on culture plates for $2 \mathrm{~h}$ to allow attachment, and then the medium was changed to DMEM containing $1 \% \mathrm{HS}, 4 \mathrm{mM}_{\mathrm{L}}$-glutamine, $100 \mathrm{U} / \mathrm{mL}$ penicillin and $100 \mu \mathrm{g} / \mathrm{mL}$ streptomycin for experiments with IONPs exposure. In all cases, the cells were cultured at $37^{\circ} \mathrm{C}$ in $5 \%$ $\mathrm{CO}_{2}$. The purity of microglial culture was $>90 \%$ as determined by flow cytometry with CD11b staining.

\section{Characterization of IONPs}

The particle size distribution and zeta potential of the IONPs were measured by phase analysis light scattering using Zetasizer nano-ZS (Malvern Instruments Ltd, Malvern, Worcestershire, UK). IONPs were appropriately diluted with $0.22 \mu \mathrm{m}$-filtered saline for size measurement at $25^{\circ} \mathrm{C}$. The zeta potentials of IONPs in saline and culture medium (DMEM containing 1\% horse serum) were measured at $25^{\circ} \mathrm{C}$.

\section{Confocal imaging of engulfed nanoparticles and lysosomes}

Microglial cells $\left(4 \times 10^{5}\right.$ cells $\left./ \mathrm{mL}\right)$ cultured on cover slips were pretreated with IONPs $(1-50 \mu \mathrm{g} \mathrm{Fe} / \mathrm{mL})$ for $30 \mathrm{~min}$ followed by stimulation with LPS (100 ng/mL; Escherichia coli O55:B5) for $24 \mathrm{~h}$. The cells were stained with $1 \mu \mathrm{M}$ LysoTracker $^{\text {Tut }}$ Red DND-99 (Invitrogen, Carlsbad, CA) for $2 \mathrm{~h}$ at $37^{\circ} \mathrm{C}$. After washing, the cells were fixed with $4 \%$ paraformaldehyde for $15 \mathrm{~min}$ at room temperature. For detection of nuclei, the fixed cells were stained with Hoechst $33258(5 \mu \mathrm{g} / \mathrm{mL})$ at room temperature for $5 \mathrm{~min}$. After washing, the cells were mounted in ProLong Gold antifade reagent (Invitrogen, Carlsbad, CA) and visualized on a Leica TCS SP5 II scanning confocal microscope (Leica Microsystems, Wetzlar, Germany).

\section{Measurement of cell viability}

The viability of microglia was determined by the 3-(4,5dimethylthiazol-2-yl)-2,5-diphenyl-tetrazolium bromide $(\mathrm{MTT})$ assay. Microglial cells $\left(4 \times 10^{5}\right.$ cells $\left./ \mathrm{mL}\right)$ were cultured in quadruplicate in a 96-well plate $(0.1 \mathrm{~mL} /$ well). The cells were either left untreated (naïve; NA), or pretreated with IONPs $(1-50 \mu \mathrm{g} \mathrm{Fe} / \mathrm{mL})$ for $30 \mathrm{~min}$ followed by stimulation with LPS $(100 \mathrm{ng} / \mathrm{mL})$ for $24 \mathrm{~h}$. An MTT stock solution $(5 \mathrm{mg} / \mathrm{mL})$ was added to each well $(10 \mu \mathrm{L} /$ well $) 4 \mathrm{~h}$ before the end of incubation. After washing, the formed formazan was dissolved by the addition of lysis buffer (10\% SDS in N,N-dimethylformamide; $200 \mu \mathrm{L} /$ well). The absorbance of the formazan product was measured at $570 \mathrm{~nm}$ and at $630 \mathrm{~nm}$ as a background reference, using a microplate reader (Dynatech Laboratories, Chantilly, VA).

\section{Measurement of cytokines}

Microglial cells $\left(4 \times 10^{5}\right.$ cells $\left./ \mathrm{mL}\right)$ were cultured in tripricate in a 48 -well plate $(0.25 \mathrm{~mL} /$ well $)$ and treated with IONPs and LPS as described above in the MTT 
assay. The supernatants were collected and quantified for IL- $1 \beta$ and TNF- $\alpha$ by standard sandwich ELISA.

\section{Measurement of ICE and TACE activity}

Microglial cells $\left(4 \times 10^{5}\right.$ cells $\left./ \mathrm{mL}\right)$ were cultured in a $6-\mathrm{cm}$ dish (5.5 mL/dish) and treated with IONPs and LPS as described above in the MTT assay. After washing, the cells were harvested and lysed with cell lysis buffer. The lysates were incubated with $200 \mu \mathrm{M}$ of the ICE fluorogenic substrates Ac-YVAD-AFC and $5 \mathrm{mM}$ of DTT for $1 \mathrm{~h}$ at $37^{\circ} \mathrm{C}$, and the fluorescence was measured at $400 \mathrm{~nm}$ excitation and $505 \mathrm{~nm}$ emissions. The cell lysates were also incubated with $40 \mu \mathrm{M}$ of the TACE fluorogenic substrate for 1 $\mathrm{h}$ at $37^{\circ} \mathrm{C}$ in the dark with gentle shaking, and the fluorescence was detected at $490 \mathrm{~nm}$ excitation and $520 \mathrm{~nm}$ emissions.

\section{Analysis of the amount of lysosomes}

Microglial cells $\left(4 \times 10^{5}\right.$ cells $\left./ \mathrm{mL}\right)$ were cultured in tripricate in a 24 -well plate $(0.5 \mathrm{~mL} /$ well $)$ and treated with IONPs and LPS as described above in the MTT assay. The cells were fixed in $4 \%$ paraformaldehyde, permeabilized with $0.2 \%$ Trion-X and incubated in blocking buffer containing $2.5 \% \mathrm{BSA}$ in PBS for $30 \mathrm{~min}$ at $4^{\circ} \mathrm{C}$. The cells were then stained with appropriately diluted APC-labeled rat anti-mouse ED-1 antibody (BioLegend, CA) for $1 \mathrm{~h}$ at $4^{\circ} \mathrm{C}$ in the dark. After washing, the fluorescence of 5000 single cells for each sample was measured using a flow cytometer at emission of $670 \mathrm{~nm}$ (BD LSRFortessa, San Jose, CA). The data were analyzed using the software Flowjo 5.7.

\section{Measurement of lysosomal acidity and permeability}

The acidity and permeability of lysosome were determined by flow cytometry using LysoSensor ${ }^{\text {TM }}$ Green DND-189 and acridine orange, respectively. Microglial cells $\left(4 \times 10^{5}\right.$ cells $/ \mathrm{mL}$ ) were cultured in tripricate in a 48 -well plate (0.25 mL/well) and treated with IONPs and LPS as described above in the MTT saasy. The cells were stained with $1 \mu \mathrm{M}$ Lysosensor ${ }^{\mathrm{Tm}}$ for $2 \mathrm{~h}$ or $5 \mu \mathrm{g} / \mathrm{mL}$ acridine orange for $10 \mathrm{~min}$ at $37^{\circ} \mathrm{C}$. After washing, the fluorescence of 5000 single cells for each sample was measured using a flow cytometer at emission of $525 \mathrm{~nm}$ and $610 \mathrm{~nm}$ for Lysosensor $^{\mathrm{TM}}$ and acridine orange, respectively.

\section{Detection of cathepsin B enzyme activity and secretory lysosomes}

Microglial cells $\left(4 \times 10^{5}\right.$ cells $\left./ \mathrm{mL}\right)$ were cultured in tripricate in a 48 -well plate $(0.25 \mathrm{~mL} /$ well $)$ and treated with IONPs and LPS as described above in the MTT assay. The cells were stained with Magic $\operatorname{Red}^{\text {Ts }}$ cathepsin $\mathrm{B}$ substrate for $1 \mathrm{~h}$ at $37^{\circ} \mathrm{C}$. Once the substrate is cleaved by active cathepsin $\mathrm{B}$, its product emits red fluorescence whose intensity is a direct measurement of the enzymatic activity of cathepsin B. After washing, the fluorescence of 5000 single cells for each sample was measured using a flow cytometer at emission of $610 \mathrm{~nm}$ and visualized on a Leica TCS SP5 II scanning confocal microscope. The secretory lysosomes in microglia were stained with appropriately diluted Alexa Fluor 488-labeled rabbit antiRab27a antibody (Bioss, MA) and visualized by confocal microscopy as described above for ED-1 staining.

\section{Statistical analysis}

The mean \pm standard error (SE) was determined for each treatment group in the individual experiments. Homogeneous data were evaluated by a parametric analysis of variance, and Dunnett's two-tailed $t$-test was used to compare treatment groups to the control group. $P$ value $<0.05$ was defined as statistical significance.

\section{Abbreviations \\ APC: Antigen-presenting cells; CNS: Central nervous system; \\ DMEM: Dulbecco's Modified Eagle Medium; ED-1: Ectodermal dysplasia-1; ELISA: Enzyme-linked immunosorbent assay; ER: Endoplasmic reticulum; FBS: Fetal bovine serum; HS: Horse serum; ICE: IL-1 $\beta$ converting enzyme; IL: Interleukin; IONPs: Iron oxide nanoparticles; LPS: Lipopolysaccharide; MFI: Mean fluorescence intensity; MRI: Magnetic resonance imaging; MTT: $3-$ (4,5-dimethylthiazol-2-yl)-2,5-diphenyl-tetrazolium bromide; NO: Nitric oxide; ROS: Reactive oxygen species; TACE: TNF-a converting enzyme; TNF: Tumor necrosis factor}

\section{Competing interests}

The authors declare that they have no competing interests.

\section{Authors' contributions}

HYW and MCC designed the research, performed experiments and drafted the paper. CCW and $\mathrm{CHH}$ provided technical aid for confocal imaging and advices for statistical analysis. HJL and TRJ provided advices for designing the research and interpreting the results, and contributed to write the manuscript. All authors read and approved the final manuscript.

\section{Acknowledgements}

This work was supported in part by grants NSC101-2321-B-002-053 and NSC102-2321-B002-040 from the National Science Council, Executive Yuan, Taiwan.

\section{Author details}

'Department and Graduate Institute of Veterinary Medicine, School of Veterinary Medicine, National Taiwan University, No.1, Sec. 4, Roosevelt Road, Taipei 10617, Taiwan. ${ }^{2}$ School of Pharmacy, Kaohsiung Medical University, No. 100, Shih-Chuan 1st Rd, Kaohsiung 80708, Taiwan. ${ }^{3}$ Department of Food Science, Yuanpei University, No.306, Yuanpei Street, Hsinchu 30015, Taiwan.

Received: 15 April 2013 Accepted: 9 September 2013

Published: 18 September 2013

\section{References}

1. Xie J, Huang J, Li X, Sun S, Chen X: Iron oxide nanoparticle platform for biomedical applications. Curr Med Chem 2009, 16:1278-1294.

2. Yu MK, Jeong YY, Park J, Park S, Kim JW, Min JJ, Kim K, Jon S: Drug-loaded superparamagnetic iron oxide nanoparticles for combined cancer imaging and therapy in vivo. Angew Chem Int Ed Engl 2008, 47:5362-5365.

3. Liong M, Lu J, Kovochich M, Xia T, Ruehm SG, Nel AE, Tamanoi F, Zink Jl: Multifunctional inorganic nanoparticles for imaging, targeting, and drug delivery. ACS Nano 2008, 2:889-896.

4. Chouly C, Pouliquen D, Lucet I, Jeune JJ, Jallet P: Development of superparamagnetic nanoparticles for MRI: effect of particle size, charge and surface nature on biodistribution. J Microencapsul 1996, 13:245-255. 
5. Shen CC, Wang CC, Liao MH, Jan TR: A single exposure to iron oxide nanoparticles attenuates antigen-specific antibody production and T-cell reactivity in ovalbumin-sensitized BALB/c mice. Int J Nanomedicine 2011, 6:1229-1235.

6. Lunov O, Syrovets T, Buchele B, Jiang X, Rocker C, Tron K, Nienhaus GU, Walther P, Mailander V, Landfester K, Simmet T: The effect of carboxydextran-coated superparamagnetic iron oxide nanoparticles on c-Jun N-terminal kinase-mediated apoptosis in human macrophages. Biomaterials 2010, 31:5063-5071.

7. Chen BA, Jin N, Wang J, Ding J, Gao C, Cheng J, Xia G, Gao F, Zhou Y, Chen $Y$, et al: The effect of magnetic nanoparticles of $\mathrm{Fe}(3) \mathrm{O}(4)$ on immune function in normal ICR mice. Int J Nanomedicine 2010, 5:593-599.

8. Cho WS, Cho M, Kim SR, Choi M, Lee JY, Han BS, Park SN, Yu MK, Jon S, Jeong J: Pulmonary toxicity and kinetic study of Cy5.5-conjugated superparamagnetic iron oxide nanoparticles by optical imaging. Toxicol Appl Pharmacol 2009, 239:106-115.

9. Hsiao JK, Chu HH, Wang YH, Lai CW, Chou PT, Hsieh ST, Wang JL, Liu HM: Macrophage physiological function after superparamagnetic iron oxide labeling. NMR Biomed 2008, 21:820-829.

10. Weinstein JS, Varallyay CG, Dosa E, Gahramanov S, Hamilton B, Rooney WD Muldoon LL, Neuwelt EA: Superparamagnetic iron oxide nanoparticles: diagnostic magnetic resonance imaging and potential therapeutic applications in neurooncology and central nervous system inflammatory pathologies, a review. J Cereb Blood Flow Metab 2010, 30:15-35.

11. Thorek DL, Weisshaar CL, Czupryna JC, Winkelstein BA, Tsourkas A: Superparamagnetic iron oxide-enhanced magnetic resonance imaging of neuroinflammation in a rat model of radicular pain. Mol Imaging 2011, 10:206-214.

12. Jin AY, Tuor UI, Rushforth D, Filfil R, Kaur J, Ni F, Tomanek B, Barber PA: Magnetic resonance molecular imaging of post-stroke neuroinflammation with a P-selectin targeted iron oxide nanoparticle. Contrast Media Mol Imaging 2009, 4:305-311.

13. Aloisi F: Immune function of microglia. Glia 2001, 36:165-179.

14. Kreutzberg GW: Microglia: a sensor for pathological events in the CNS. Trends Neurosci 1996, 19:312-318.

15. Giulian D, Lachman LB: Interleukin-1 stimulation of astroglial proliferation after brain injury. Science 1985, 228:497-499.

16. Gehrmann J, Matsumoto Y, Kreutzberg GW: Microglia: intrinsic immuneffector cell of the brain. Brain Res Brain Res Rev 1995, 20:269-287.

17. Lee SC, Dickson DW, Brosnan CF: Interleukin-1, nitric oxide and reactive astrocytes. Brain Behav Immun 1995, 9:345-354.

18. Mason JL, Suzuki K, Chaplin DD, Matsushima GK: Interleukin-1beta promotes repair of the CNS. J Neurosci 2001, 21:7046-7052.

19. Smith JA, Das A, Ray SK, Banik NL: Role of pro-inflammatory cytokines released from microglia in neurodegenerative diseases. Brain Res Bull 2012, 87:10-20.

20. Hanisch UK: Microglia as a source and target of cytokines. Glia 2002, 40:140-155.

21. Hutter E, Boridy S, Labrecque S, Lalancette-Hebert M, Kriz J, Winnik FM, Maysinger D: Microglial response to gold nanoparticles. ACS Nano 2010, 4:2595-2606.

22. Wang $Y$, Wang B, Zhu MT, Li M, Wang HJ, Wang M, Ouyang $H$, Chai ZF, Feng WY, Zhao YL: Microglial activation, recruitment and phagocytosis as linked phenomena in ferric oxide nanoparticle exposure. Toxicol Lett 2011, 205:26-37.

23. Shen CC, Liang HJ, Wang CC, Liao MH TRJ: A role of cellular glutathione in the differential effects of iron oxide nanoparticles on antigen-specific $T$ cell cytokine expression. Int J Nanomedicine 2011, 6:2791-2798.

24. Mou Y, Chen B, Zhang Y, Hou Y, Xie H, Xia G, Tang M, Huang X, Ni Y, Hu Q: Influence of synthetic superparamagnetic iron oxide on dendritic cells. Int J Nanomedicine 2011, 6:1779-1786.

25. Yang CY, Tai MF, Lin CP, Lu CW, Wang JL, Hsiao JK, Liu HM: Mechanism of cellular uptake and impact of ferucarbotran on macrophage physiology. Plos one 2011, 6:e25524.

26. Yeh $\mathrm{CH}$, Hsiao JK, Wang JL, Sheu F: Immunological impact of magnetic nanoparticles (Ferucarbotran) on murine peritoneal macrophages. J Nanoparticle Res: Interdiscip Forum Nanoscale Sci Technol 2010, 12:151-160.

27. Ankamwar B, Lai TC, Huang JH, Liu RS, Hsiao M, Chen CH, Hwu YK: Biocompatibility of $\mathrm{Fe}(3) \mathrm{O}(4)$ nanoparticles evaluated by in vitro cytotoxicity assays using normal, glia and breast cancer cells. Nanotechnol 2010, 21:75102.
28. Li X, Xu S, Zhang Z, Schluesener H: Apoptosis induced by titanium dioxide nanoparticles in cultured murine microglia N9 cells. Chin Sci Bull 2009, 54:3830-3836.

29. Yeh C-H, Hsiao J-K, Wang J-L, Sheu F: Immunological impact of magnetic nanoparticles (Ferucarbotran) on murine peritoneal macrophages. J Nanopart Res 2010, 12:151-160.

30. Chauvet N, Palin K, Verrier D, Poole S, Dantzer R, Lestage J: Rat microglial cells secrete predominantly the precursor of interleukin-1beta in response to lipopolysaccharide. Eur J Neurosci 2001, 14:609-617.

31. Black RA: Tumor necrosis factor-alpha converting enzyme. Int J Biochem Cell Biol 2002, 34:1-5.

32. Stow JL, Low PC, Offenhauser C, Sangermani D: Cytokine secretion in macrophages and other cells: pathways and mediators. Immunobio/ 2009, 214:601-612.

33. Lacy P, Stow JL: Cytokine release from innate immune cells: association with diverse membrane trafficking pathways. Blood 2011, 118:9-18.

34. Nickel W: The mystery of nonclassical protein secretion. A current view on cargo proteins and potential export routes. Eur J Biochem 2003, 270:2109-2119.

35. Nickel W, Rabouille C: Mechanisms of regulated unconventional protein secretion. Nat Rev Mol Cell Biol 2009, 10:148-155.

36. Eder C: Mechanisms of interleukin-1beta release. Immunobio/ 2009, 214:543-553.

37. Choi J, Zheng Q, Katz HE, Guilarte TR: Silica-based nanoparticle uptake and cellular response by primary microglia. Environ Health Perspect 2010, 118:589-595.

38. Lunov O, Syrovets T, Rocker C, Tron K, Nienhaus GU, Rasche V, Mailander V, Landfester K, Simmet T: Lysosomal degradation of the carboxydextran shell of coated superparamagnetic iron oxide nanoparticles and the fate of professional phagocytes. Biomaterials 2010, 31:9015-9022.

39. Terada K, Yamada J, Hayashi Y, Wu Z, Uchiyama Y, Peters C, Nakanishi H: Involvement of cathepsin B in the processing and secretion of interleukin-1beta in chromogranin A-stimulated microglia. Glia 2010, 58:114-124.

40. Lunov O, Zablotskii V, Syrovets T, Rocker C, Tron K, Nienhaus GU, Simmet T: Modeling receptor-mediated endocytosis of polymer-functionalized iron oxide nanoparticles by human macrophages. Biomaterials 2011, 32:547-555.

41. Luther EM, Petters C, Bulcke F, Kaltz A, Thiel K, Bickmeyer U, Dringen R: Endocytotic uptake of iron oxide nanoparticles by cultured brain microglial cells. Acta biomaterialia 2013, 9:8454-8465.

42. Blott EJ, Griffiths GM: Secretory lysosomes. Nat Rev Mol Cell Biol 2002, 3:122-131.

43. Griffiths G: What's special about secretory lysosomes? Semin Cell Dev Biol 2002, 13:279-284.

44. Elstak ED, Neeft M, Nehme NT, Voortman J, Cheung M, Goodarzifard M, Gerritsen HC, van Bergen En Henegouwen PM, Callebaut I, de Saint Basile G, van der Sluijs $P$ : The munc13-4-rab27 complex is specifically required for tethering secretory lysosomes at the plasma membrane. Blood 2011, 118:1570-1578.

45. Ostrowski M, Carmo NB, Krumeich S, Fanget I, Raposo G, Savina A, Moita CF, Schauer K, Hume AN, Freitas RP, et al: Rab27a and Rab27b control different steps of the exosome secretion pathway. Nat Cell Biol 2010, 12:19-30. sup pp 11-13.

46. Guha S, Padh H: Cathepsins: fundamental effectors of endolysosomal proteolysis. Indian J Biochem Biophys 2008, 45:75-90.

47. Mort JS, Buttle DJ: Cathepsin B. Int J Biochem Cell Biol 1997, 29:715-720.

48. Trombetta ES, Ebersold M, Garrett W, Pypaert M, Mellman I: Activation of lysosomal function during dendritic cell maturation. Science 2003, 299:1400-1403.

49. Ma X, Wu Y, Jin S, Tian Y, Zhang X, Zhao Y, Yu L, Liang XJ: Gold nanoparticles induce autophagosome accumulation through sizedependent nanoparticle uptake and lysosome impairment. ACS Nano 2011, 5:8629-8639.

50. Smith ME, van der Maesen K, Somera FP: Macrophage and microglial responses to cytokines in vitro: phagocytic activity, proteolytic enzyme release, and free radical production. J Neurosci Res 1998, 54:68-78.

51. Honey K, Rudensky AY: Lysosomal cysteine proteases regulate antigen presentation. Nat Rev Immunol 2003, 3:472-482.

52. Long TC, Tajuba J, Sama P, Saleh N, Swartz C, Parker J, Hester S, Lowry GV, Veronesi $\mathrm{B}$ : Nanosize titanium dioxide stimulates reactive oxygen species 
in brain microglia and damages neurons in vitro. Environ Health Perspect 2007, 115:1631-1637.

53. Correa F, Docagne F, Mestre L, Clemente D, Hernangomez M, Loria F, Guaza C: A role for $C B 2$ receptors in anandamide signalling pathways involved in the regulation of IL-12 and IL-23 in microglial cells. Biochem Pharmacol 2009, 77:86-100.

doi:10.1186/1743-8977-10-46

Cite this article as: Wu et al:: Iron oxide nanoparticles suppress the production of IL-1 beta via the secretory lysosomal pathway in murine microglial cells. Particle and Fibre Toxicology 2013 10:46.

\section{Submit your next manuscript to BioMed Central and take full advantage of:}

- Convenient online submission

- Thorough peer review

- No space constraints or color figure charges

- Immediate publication on acceptance

- Inclusion in PubMed, CAS, Scopus and Google Scholar

- Research which is freely available for redistribution 